\title{
Komunikasi Antarbudaya Dalam Program Acara Sandya Kala Gita (Studi Komunikasi Hindu di Radio Genta Bali)
}

I Dewa Gede Putu Budiyasaa

Prodi Magister Ilmu Komunikasi Hindu Pascasarjana

Institut Hindu Dharma Negeri Denpasar

\begin{abstract}
Intercultural communication aims at forming harmonious life, bringing together two or more people from different cultures to form a new culture. Trust or religion is part of culture. Intercultural communication can basically form a new culture. Mass media plays an important role in people's lives in the process of sending information and reciprocal processes. This paper examines how the intercultural communication process is delivered through Radio media. The process of intercultural communication in the program Sandya Kala Gita is seen as a transactional process that affects the behavior of communicators and communicants intentionally, aware of the behavior to produce messages that are channeled through channels to stimulate or obtain certain attitudes or behaviors. Intercultural communication on the Sandya Kala Gita program shows implications for the strengthening of cognitive communicants, the affective formation of communicators and communicants, and behavioral development for communicators and communicants.
\end{abstract}

Keywords Communication, Radio, Intercultural communication, Sandya Kala Gita

\section{PENDAHULUAN}

Komunikasi sangat memegang peranan penting dalam kehidupan manusia. Sifat alami komunikasi manusia dapat terpenuhi jika melakukan interaksi sehingga terjadi tindakan aksi dan reaksi. Aksi dan reaksi yang dilakukan oleh manusia disebut dengan tindakan komunikasi. Komunikasi memberikan kesempatan seseorang untuk menyampaikan apa yang ada dalam pikirannya kepada orang lain baik secara langsung maupun tidak langsung. Komunikasi juga dikatakan sebagai suatu proses karena termasuk kegiatan dinamis yang berlangsung secara berkesinambungan. Proses tersebut

\footnotetext{
a dewa_budiyasa@gmail.com
} 
merupakan proses yang disengaja. Komponen komunikasi mempunyai tugas atau karakter yang berbeda, namun saling mendukung terjadinya sebuah proses komunikasi. Proses komunikasi juga memiliki tujuan. Tujuan manusia berkomunikasi bermacammacam yaitu hanya sekedar iseng, sebagai penyampaian informasi, dapat menambah pengetahuan dan mengubah sikap atau perilaku. Hal ini sesuai dengan definisi komunikasi yang dikemukakan oleh Rogers dalam Cangara (2010:22) yaitu suatu proses pengalihan ide dari sumber kepada satu penerima atau lebih dengan maksud mengubah perilaku. Komunikasi tidak hanya bertujuan untuk perubahan perilaku tetapi juga perubahan pemikiran, membentuk budaya dan menjembatani manusia.

Media massa adalah semua sarana yang digunakan untuk memproduksi, mereproduksi, mendistribusikan dan menyampaikan informasi. Media massa sangat berperan dalam kehidupan masyarakat dalam proses pengiriman informasi dan proses timbal balik. Menurut Nurudin (2007:9) untuk menyebarkan informasi, media massa sangat efektif mengubah sikap, pendapat dan perilaku komunikasi. Media massa yaitu alat-alat dalam komunikasi yang bisa menyebarkan pesan secara serempak, cepat kepada audiens yang luas dan heterogen. Media massa memiliki kelebihan dibanding dengan jenis komunikasi lain yaitu dapat mengatasi hambatan ruang dan waktu. Radio merupakan media massa yang tergolong cepat karena tepat waktu dan menggunakan siaran langsung. Umumnya radio merupakan media massa satu arah yang sumbernya kepada sasaran dan sasaran tidak dapat atau tidak mempunyai kesempatan untuk memberikan umpan balik atau memberikan tanggapan. Tetapi saat ini radio dapat dikembangkan sebagai bagian dari media komunikasi dua arah, yaitu dipadukan dengan telepon. Komunikasi dua arah dari radio yang memadukan telepon dapat memberi kesempatan kepada masyarakat pendengar untuk melakukan interaksi sehingga dapat terjadinya komunikasi. Radio dapat digunakan sebagai media interaktif membuka kesempatan bagi pendengar untuk melakukan hubungan timbal balik dengan pengirim informasi dari sebuah stasiun radio tertentu.

Keunggulan radio lainnya yaitu merupakan media yang dapat dijangkau diseluruh tempat dari desa hingga ke kota. Radio dapat didengar oleh seluruh penikmatnya. Adanya radio memudahkan masyarakat pendengar untuk memperoleh informasi. Oleh karenanya, Radio Genta Bali hadir sebagai salah satu radio milik swasta yang selalu menyuguhkan informasi dengan menggunakan Bahasa Bali yang berlandaskan budaya dan agama Hindu. Tampilnya Radio Genta Bali dalam ciri khasnya melestarikan budaya Bali berlandaskan agama Hindu sebagai daya tarik penggemarnya. Seluruh program acara yang terdapat di Radio Genta Bali menggunakan Bahasa Bali dengan genre siaran yang sesuai dengan aturan perundang-undangan yang berlaku serta diawasi langsung oleh Komisi Penyiaran Indonesia Daerah (KPID) Bali. Genre siarannya antara lain : siaran hiburan $20 \%$, siaran informasi $20 \%$, siaran musik $45 \%$, siaran pendidikan $10 \%$ dan siaran agama $5 \%$ sehingga total menjadi $100 \%$. Prosentase siaran musik yang paling tinggi merupakan hal penting bagi Radio Genta Bali karena disinilah pokok tujuannya untuk melestarikan budaya 
Bali dengan memberikan porsi 95\% pada musik tradisional atau daerah sisanya 5\% pada musik Indonesia popular dengan waktu siaran dari pukul 05.00 sampai dengan 24.00 wita.

\section{PEMBAHASAN}

\section{Proses Komunikasi Antarbudaya Dalam Program Acara Sandya Kala Gita di Radio Genta Bali}

Program acara adalah segala hal yang ditampilkan stasiun penyiaran untuk memenuhi kebutuhan audiensnya. Dengan demikian, program memiliki pengertian yang sangat luas. Program acara yang disajikan merupakan faktor yang membuat audiens tertarik untuk mengikuti siaran yang dipancarkan stasiun penyiaran baik radio maupun televisi. Jenis program acara dapat dikelompokkan menjadi dua bagian besar berdasarkan jenisnya yaitu : 1) program informasi (berita) dan 2) program hiburan (entertainment). Selanjutnya, program informasi kemudian dibagi lagi menjadi dua jenis yakni berita keras dan berita lunak. Berita keras (hard news) merupakan laporan berita terkini yang harus segera disiarkan dan berita lunak (soft news) yang merupakan kombinasi dari fakta, gosip dan opini. Sementara program hiburan terbagi atas tiga kelompok besar yakni musik, drama permainan (game show), dan pertunjukan (Morissan, 2013:218).

Format siaran di Indonesia menjadi wajib dimiliki stasiun penyiaran. Pada umumnya stasiun radio memproduksi sendiri program siarannya. Begitu pula dengan Radio Genta Bali. Program acara yang terdapat di Radio Genta Bali berlandaskan budaya dan agama Hindu. Program acara yang disiarkan langsung oleh penyiar dan pengasuh program acara yang dipertanggungjawabkan oleh kepala studio. Salah satu program acara unggulan yang terdapat di Radio Genta Balai yakni program acara Sandya Kala Gita. Program acara Sandya Kala Gita muncul karena banyak saran-saran dari masyarakat yang masuk ke studio Radio Genta Bali. Animo masyarakat yang menginginkan siaran berita yang disisipi dengan lagu-lagu Bali, namun dalam proses siaran berlangsung masyarakat bisa memberikan respon tentang suatu informasi yang terkini melalui telepon. Oleh karenanya, manajemen Radio Genta Bali menginput saran-saran dari masyarakat dan mendiskusikannya. Setelah melalui proses uji materi maka program acara Sandya Kala Gita hadir menjadi program acara unggulan di Radio Genta Bali.

\section{Proses Siaran Program Acara Sandya Kala Gita di Radio Genta Bali}

Schramm dalam Cangara (2016:33-42) mengklasifikasikan proses komunikasi menjadi empat yaitu (1) proses komunikasi secara primer, (2) proses komunikasi secara sekunder, (3) proses komunikasi secara linier dan (4) proses komunikasi secara sirkular. Proses komunikasi membutuhkan serangkaian kegiatan timbal balik antara komunikator dengan komunikan. Adanya pengulangan siklus komunikasi memaksimalkan pencapaian tujuan komunikasi. Proses komunikasi mempunyai dua model yaitu model linier dan model sirkular. Model linier yaitu proses komunikasi hanya terjadi dua garis lurus, dimana proses komunikasi berawal dari komunikator kepada komunikan. Sedangkan model sirkular ditandai dengan adanya unsur timbal balik atau feedback. Dengan demikian 
proses komunikasi tidak berawal dari satu titik dan berakhir pada titik yang lain. Jadi proses komunikasi sirkular itu berbalik satu lingkaran penuh.

Proses penyiaran terjadi sejak ide itu diciptakan sampai dengan ide itu disebarluaskan. Proses siaran program acara Sandya Kala Gita langkahlangkahnya meliputi : tahap program, tahap teknis dan tahap penyiaran.

\section{Tahap Program di Radio Genta Bali}

Kreativitas program siaran di Radio Genta Bali sebenarnya tergantung pada sejauhmana tim kreatif bisa mengeluarkan ide-ide unik terkait dengan program acara dan bagaimana mengeksekusinya dalam sebuah program acara. Program acara tidak asal mengudara begitu saja tetapi harus memiliki nilai lebih, disenangi dan diminati pendengar. Program acara kedepannya, tentu bisa menjadi peluang bisnis terutama untuk meraih iklan sebanyak-banyaknya. Rumusan program acara di Radio Genta Bali dimulai dari penggagas ide yang dalam hal ini adalah komunikator yakni tim kreatif. Tim kreatif menyusun program acara dengan memperhatikan segmentasi dan pola siaran dengan ciri khas budaya Bali. Isu dan gaya hidup masyarakat baik dalam bidang sosial, budaya, pendidikan, ekonomi dan politik sangat diperhatikan oleh komunikator dalam merancang sebuah program acara. Kemudian ide diubah menjadi suatu bentuk pesan yang dapat dikirimkan baik verbal maupun nonverbal melalui saluran atau sarana komunikasi yang memungkinkan pesan itu mampu menjangkau khalayak luas (komunikan). Ide yang sudah dirancang menjadi pesan siaran selanjutnya disebut dengan sketsa program acara.
Sketsa program acara di Radio Genta Bali sebelum dinyatakan layak siar perlu dilakukan pengkajian melalui rapat program siaran. Rapat program siaran merupakan langkah awal dalam merumuskan sebuah program acara. Dalam rapat program siaran, tim kreatif mencurahkan berbagai macam ide terkait program acara kepada Kepala Studio Radio Genta Bali. Kepala Studio akan memutuskan ide mana yang paling bagus dan memenuhi kriteria sebuah program acara bisa di-launching ke khalayak ramai. Setelah ide program acara disetujui dalam rapat program siaran, maka selanjutnya yang harus dilakukan adalah mengurai secara detail bagaimana mengeksekusi ide tersebut menjadi program acara yang bisa dijalankan secara on air.

Program acara di Radio Genta Bali bisa diuraikan secara detail tentang kapan program acara tersebut akan disiarkan, berapa durasinya, berapa biaya produksinya, siapa produsernya, siapa tim produksi, siapa penyiarnya, dan masih banyak hal detail yang harus dijabarkan. Hal ini dimaksudkan, ketika eksekusi program acara tidak ada lagi kendala dan tim akan benar-benar paham dalam proses siaran program acara tersebut. Proses siaran di Radio Genta Bali yang memiliki ciri khas budaya Bali khususnya Bahasa Bali, maka setiap penyiar diwajibkan menguasai Bahasa Bali sebagai bahasa pengantar siarannya.

\section{Tahap Teknis di Radio Genta Bali}

Radio Genta Bali dalam proses siarannya sudah menggunakan tiga unsur Trilogi Penyiaran yaitu studio, transmitter dan pesawat penerima. Untuk studio Radio Genta Bali terletak di lantai 3 Gedung Pers Bali K. Nadha di Jalan Kebo Iwa 63 A Denpasar. Adapun 
transmitter yang digunakan masih direlay dari satelit bersama Bali TV yang juga merupakan perusahaan media dibawah bendera Kelompok Bali Post (KMB). Sedangkan untuk pesawat penerima masing-masing stasiun radio sudah memilikinya.

Studio merupakan sistem yang cukup berperan dalam sebuah stasiun penyiaran. Sebagai subsistem yang terintegrasi secara total, bagian studio memberikan andil untuk penyedia program-program reguler yang sifatnya berkesinambungan. Sistem studio pada umumnya terintegrasi dari berbagai unit sistem seperti bagian audio, video sistem, dan pencahayaan serta dilengkapi prasarana seni atau gambar sebagai pendukung produksi khususnya untuk produksi audio visual. Studio juga sebagai tempat produksi informasi sekaligus menyiarkan, yakni mengubah ide dan gagasan menjadi bentuk pesan baik gambar maupun suara. Studio Radio Genta Bali sebagai penyuplai program acara dibagi dalam dua kategori besar : (1) siaran langsung seperti program berita yang memiliki kekuatan informasi untuk segera disiarkan, dan (2) siaran rekam yaitu program acara yang direkam terlebih dahulu baik program acara non drama seperti musik, olahraga dan program acara drama.

Transmitter merupakan salah satu unsur dalam proses penyiaran yang berfungsi mengantarkan gambar dan suara dari studio berupa gelombang elektromagnetik yang membawa muatan informasi untuk dipancarkan atau disalurkan melalui kabel atau serat optik. Ada tiga cara sistem satelit komunikasi yaitu 1) Sistem DBS (Panduan Satelit Penyiaran), 2) Sistem Semi DBS, dan 3) Sistem gabungan (penyaluran dan satelit). Transmiiter yang dipergunakan
Radio Genta Bali yakni di-relay dari transmitter Bali TV.

\section{Tahap Penyiaran di Radio Genta Bali}

Produksi penyiaran merupakan kegiatan penyelenggaraan siaran yaitu rangkaian mata acara dalam bentuk audio, suara atau visual gambar yang ditransmisikan dalam bentuk signal suara atau gambar, baik melalui udara maupun melalui kabel atau serat optik yang dapat diterima oleh pesawat penerima di masing-masing rumah. Proses siaran terjadi sejak ide diciptakan sampai dengan ide itu disebarluaskan. Studio merupakan sistem yang cukup berperan dalam sebuah stasiun penyiaran, sebagai subsistem yang terintegrasi secara total, bagian studio memberikan andil untuk penyedia program-program regular yang bersifat berkesinambungan. Langkah-langkahnya meliputi penggagas ide yang dalam hal ini disebut sebagai komunikator atau narasumber program acara, kemudian ide tersebut diubah bentuknya menjadi sebuah pesan yang dapat dikirimkan secara verbal maupun nonverbal melalui saluran komunikasi dalam hal ini Radio Genta Bali supaya dapat didengar atau dijangkau oleh khalayak pendengar. Dalam program acara Sandya Kala Gita di Radio Genta Bali menggunakan konsep berita, dialog interaktif dan lagu-lagu Bali sebagai selingan hiburan untuk pendengar.

Proses siaran program acara Sandya Kala Gita di Radio Genta Bali termasuk dalam model sirkuler ditandai dengan adanya unsur timbal balik atau feedback. Proses timbal balik atau feedback ini dapat dilihat saat proses dialog interaktif. Komunikator dalam hal ini penyiar program acara Sandya Kala Gita membuka secara luas kepada 
khalayak pendengar untuk berpartisipasi memberikan respon, opini atau informasi baru terkait dengan siaran program acara Sandya Kala Gita. Khalayak pendengar bisa memberikan tanggapan melalui line telepon yang telah disediakan oleh komunikator sehingga interaksi antara komunikator dan komunikan terjadi secara dua arah.

\section{Sambutan Pendengar Program Acara Sandya Kala Gita di Radio Genta Bali}

Media secara potensial mempengaruhi situasi dan norma bagi individu-individu dengan cara : 1) Pesan komunikasi massa akan memperkuat pola-pola yang sedang berlaku dan memandu khalayak untuk percaya bahwa suatu bentuk sosial tertentu tengah dibina oleh masyarakat, 2) Media komunikasi dapat menciptakan keyakinan baru mengenai hal-hal dimana khalayak sedikit banyak telah memiliki pengalaman sebelumnya, dan 3) Komunikasi massa dapat mengubah norma-norma yang tengah berlaku dan karenanya mengubah khalayak dari suatu bentuk perilaku menjadi bentuk perilaku yang lain (Mulyana, 2008:119122). Hubungan yang potensial antara media massa dengan norma untuk memperjelas tentang fungsi media dalam memperkuat norma. Media beroperasi secara perlahan-lahan dan mengikuti norma umum yang berkaitan dengan cita rasa dan nilai daripada membawanya dalam bentuk-bentuk yang baru. Jadi, media massa memperkuat status quo daripada menciptakan norma-norma baru atau mengubah pola-pola terlembaga secara mendalam.

Radio dapat dinikmati pendengar sambil melakukan aktivitas-aktivitas lainnya. Radio dapat menjangkau daerah-daerah yang sulit dijangkau oleh media cetak. Pendengar radio dapat dijangkau dalam seketika, dan pesanpesan yang disampaikan lewat radio menimbulkan efek imajinasi yang besar. Namun, radio memiliki sifat lokal yaitu daya jangkauan yang terbatas. Oleh karena itu, dalam radius jangkauannya radio harus memiliki segmentasi yang jelas dan tajam siapa yang ingin dijangkaunya. Radio sangat penting menentukan segmentasi sebelum memulai aktivitas siaran. Segmentasi yang jelas akan menentukan format siaran yang meliputi pemilihan program acara dan gaya siaran sesuai dengan target audiens atau khalayak pendengar yang dituju. Tujuan penentuan format siaran adalah untuk memenuhi sasaran khalayak secara spesifik dan kesiapan berkompetisi dengan radio lain di suatu lokasi siaran yang berdekatan. Segmentasi merupakan satu kesatuan dengan targeting dan positioning. Targeting atau menetapkan target audiens adalah tahap selanjutnya dari analisis segmentasi. (Morissan, 2013:178).

Segmentasi pasar audiens adalah suatu konsep yang sangat penting dalam memahami audiens penyiaran dan pemasaran program. Segmentasi pasar dibagi ke dalam kelompok-kelompok yang jelas yakni : 1) memiliki kebutuhan yang sama, dan 2) memberi respon yang sama terhadap suatu tindakan pemasaran (Morissan, 2013:178-179). Khalayak audiens umum memiliki sifat yang hetrogen, maka akan sulit bagi media penyiaran untuk melayani semuanya. Oleh karena itu, harus dipilih segmen-segmen audiens tertentu saja. Radio Genta Bali memiliki ciri khas pada segmentasinya. Semua program acara yang ada di Radio Genta Bali, bahasa 
pengantarnya menggunakan Bahasa Bali. Karena Radio Genta Bali memiliki tekad yang kuat untuk melestarikan budaya Bali terutama mengedepankan Bahasa Bali di masyarakat. Begitupula dengan program acara Sandya Kala Gita bahasa pengantarnya dominan menggunakan Bahasa Bali walaupun siaran ini merupakan berita yang dikemas dengan dialog interaktif namun tetap memiliki segementasi budaya yang kuat. Disamping itu pula, program acara Sandya Kala Gita memiliki audiens yang beranekaragam budaya dan agama, sehingga audiens merupakan masyarakat multikultur yang tinggal di daerah-daerah yang termasuk dalam coverage area Radio Genta Bali. Penyiar selalu merespon telepon yang masuk dari audiens pendengar dengan salam 'Om Swastyastu" dan secara otomatis respon audiens pendengarpun sama dengan menjawab salam 'Om Swastyastu”. Begitupun selanjutnya, komunikasi berlangsung dengan menggunakan Bahasa Bali sehingga keakraban terjadi dalam proses komunikasi dialog intraktif. Komunikan yang memberikan tanggapan melalui telepon yang berbeda budaya dan agama tidak merasa canggung dalam merespon salam yang disampaikan penyiar.

Sambutan pendengar dalam program acara Sandya Kala Gita sesuai dengan data yang terdapat di Radio Genta Bali sangat baik karena hampir $94,3 \%$ audiens pendengar menyatakan senang dan selalu mengikuti program acara Sandya Kala Gita karena ingin mengetahui informasi yang akurat dan terjamin kebenaran. Kelebihan dalam program acara Sandya Kala Gita yakni merupakan berita sinergi dari surat kabar yang tergabung dalam Kelompok
Media Bali Post (KMB) kembali diulas dalam konsep dialog interaktif sehingga masyarakat pendengar bisa ikut urun pendapat namun masih tetap memperhatikan etika kesopanan sesuai kaidah-kaidah yang berlaku.

Berdasarkan umpan balik yang diberikan oleh komunikan, pihak Radio Genta Bali khususnya yang terlibat dalam program acara Sandya Kala Gita tetap berupaya memberikan yang terbaik dan informasi yang up to date. Program acara Sandya Kala Gita juga pernah mendapatkan penghargaan dari Komisi Penyiaran Indonesia Daerah (KPID) Bali sebagai program acara terbaik versi informasi dan dialog interkatif. Disamping itu pula Radio Genta Bali beberapa kali meraih penghargaan sebagai radio yang segmentasinya memegang teguh budaya Bali terutama dalam upaya pelestarian Bahasa Bali. Berdasarkan penghargaan yang pernah diraih, tidak bisa lepas dari peran yang sangat baik dari audiens pendengar sehingga program acara Sandya Kala Gita menduduki rating yang sangat baik dan menjadi program acara unggulan di Radio Genta Bali.

\subsubsection{Proses Komunikasi}

Antarbudaya dalam Program Acara Sandya Kala Gita di Radio Genta Bali

Budaya dan komunikasi pada intinya tidak dapat dipisahkan. Budaya tidak hanya menentukan siapa bicara siapa, tentang apa dan bagaimana komunikasi itu berlangsung. Budaya juga turut menentukan orang menyandi pesan, makna yang dimiliki untuk pesan dan kondisi-kondisi untuk mengirim, memperhatikan dan menafsirkan pesan. Sebenarnya, seluruh perilaku sangat tergantung pada budaya. Konsekwensinya, budaya merupakan landasan komunikasi. Bila budaya 
beraneka ragam maka beragam pula praktik-praktik komunikasi. Budaya dan komunikasi menjelmakan diri dalam kerangka interaksi. Interaksi ini sebagai pengejawantahan wacana sosial yang memberi ukuran dan bentuk dialog budaya baik dengan sesama budaya maupun dengan budaya yang berbeda.

Komunikasi antarbudaya terjadi bila produsen pesan adalah anggota suatu budaya lain dan penerima pesannya anggota budaya lain. Proses komunikasi antarbudaya menunjukkan bahwa bisa terdapat banyak ragam perbedaan budaya dalam komunikasi antarbudaya. Sehingga komunikasi antarbudaya terjadi dalam banyak ragam situasi yang berkisar dari ragam interaksi antara orang-orang yang berbeda budaya secara ekstrem hingga interaksi antara orang-orang yang memiliki budaya dominan yang sama tetapi memiliki subkultur dan subkelompok berbeda.

Proses komunikasi antarbudaya dalam program acara Sandya Kala Gita di Radio Genta Bali menggunakan model sirkuler ditandai dengan adanya unsur timbal balik atau feedback saat terjadi dialog interaktif dan saat temu fans setiap hari Minggu sore bertempat di Wantilan Bali TV. Proses komunikasi antarbudaya juga dapat dilihat dari proses interaksinya seperti dalam komunikasi antarpribadi, komunikasi intrapribadi, komunikasi kelompok dan komunikasi organisasi. Selanjutnya program acara Sandya Kala Gita berperan sebagai pusat pesan sehingga dapat diterima oleh audiens dan masyarakat luas sesuai dengan intepretasi masing-masing.

\section{Fungsi Komunikasi Antarbudaya Dalam Program Acara Sandya Kala Gita di Radio Genta Bali}

Komunikasi massa memiliki ciri tersendiri seperti sifat pesannya terbuka dengan khalayak yang variatif baik dari segi usia, agama, suku, pekerjaan maupun segi kebutuhan. Ciri lain yang dimiliki oleh komunikasi massa adalah sumber dan penerima dihubungkan oleh saluran yang telah diproses secara mekanik. Sumber juga merupakan suatu lembaga atau institusi yang terdiri dari banyak orang, misalnya : reporter, penyiar, editor, teknisi dan lain sebagainya. Karena proses penyampaian pesannya lebih formal, terencana dan lebih rumit. Pesan komunikasi massa berlangsung satu arah dan tanggapan umpan baliknya lambat atau tertunda dan sangat terbatas. Tetapi dengan perkembangan teknologi komunikasi yang begitu cepat khususnya media massa elektronik seperti radio dan televisi maka umpan balik dari khalayak bisa dilakukan dengan cepat kepada penyiar. Sifat penyebaran pesan melalui media massa berlangsung begitu cepat, serempak dan luas. Bahkan mampu mengatasi jarak dan waktu serta tahan lama bila didokumentasikan. Dari segi ekonomi, biaya produksi komunikasi massa cukup mahal dan memerlukan dukungan tenaga relatif banyak untuk mengelolanya.

Komunikasi massa berfungsi untuk menyebarluaskan informasi, meratakan pendidikan, merangsang pertumbuhan ekonomi dan menciptakan kegembiraan dalam hidup seseorang. Tetapi dengan perkembangan teknologi komunikasi yang begitu cepat terutama dalam bidang penyiaran dan media pandang audiens pendengar (audiovisual) menyebabkan fungsi media 
massa telah banyak mengalami perubahan. Fungsi komunikasi antarbudaya dalam program acara Sandya Kala Gita di Radio Genta Bali, maka fungsi komunikasi antarbudaya yang akan dibahas yaitu fungsi pendidikan, fungsi sosial budaya, fungsi pelestarian budaya dan agama Hindu, serta fungsi hiburan.

Fungsi pendidikan dalam komunikasi massa khususnya radio merupakan fungsi yang dilakukan oleh komunikasi massa dalam memberikan pendidikan kepada masyarakat untuk berfikir kritis dan memiliki pengetahuan yang luas. Fungsi pendidikan juga memiliki peran dalam melestarikan dan mewariskan nilai-nilai sosial dari suatu generasi kepada generasi berikutnya. Dalam menjalankan fungsi media massa terutama radio biasanya mengemas acara dalam bentuk artikel, talkshow atau dialog interaktif. Fungsi sosial budaya terdapat beberapa perilaku komunikasi individu dalam interaksi sosial. Perilaku dinyatakan dengan tindakan komunikasi baik secara verbal maupun nonverbal. Fungsi sosial budaya memiliki beberapa bidang yaitu pengawasan, menjembatani dan sosialisasi nilai.

\section{Implikasi Komunikasi Antarbudaya Dalam Program Acara Sandya Kala Gita di Radio Genta Bali}

Implikasi

komunikasi

antarbudaya dalam program acara Sandya Kala Gita dapat memberikan beberapa dampak terhadap khalayak. Adapun dampak dari implikasi komunikasi antarbudaya dalam program acara Sandya Kala Gita yaitu penguatan kognitif, pembentukan afektif dan pengembangan behavioral. Penguatan kognitif pada media massa dapat $\begin{array}{lcr}\text { membantu } & \text { khalayak } & \text { dalam } \\ \text { mendapatkan } & \text { informasi } & \text { yang } \\ \text { bermanfaat } & \text { dan } & \text { mampu }\end{array}$ mengembangkan keterampilan kognitif. Melalui media massa diperoleh juga informasi tentang benda, orang atau tempat yang belum pernah dikunjungi. Realitas yang ditampilkan oleh media massa sudah diseleksi bukan merupakan kecendrungan.

Penguatan komunikasi antarbudaya dalam program acara Sandya Kala Gita di Radio Genta Bali memberikan dampak terhadap audiens pendengarnya. Salah satu dampak dari komunikasi antarbudaya dalam program acara Sandya Kala Gita adalah sebagai penguatan kognitif. Penguatan kognitif merupakan peningkatan pengetahuan. Pembentukan afektif yaitu berkaitan dengan perubahan sikap, pemikiran dan persepsi. Aspek pembentukan afektif mencakup watak perilaku seperti perasaan, minat, sikap, emosi dan nilai. Akibat dari mendapatkan informasi seseorang dapat merasakan sesuatu, bisa merasa senang, bahagia, sedih, merinding dan lain sebagainya. Efek dari komunikasi yang mempengaruhi perasaan khalayak termasuk dalam pembentukan afektif. Dari pengaruh perasaan yang timbul akibat komunikasi selanjutnya mempengaruhi sikap yang ditunjukkan khalayak.

Pengembangan behavioral yaitu berkaitan dengan perubahan perilaku. Pengembangan behavioral merupakan akibat yang timbul pada diri khalayak dalam bentuk perilaku, tindakan atau kegiatan. Pengembangan behavioral tersebut dapat berupa banyak hal, misalnya pelestarian budaya, dampak sosial, dampak religius dan lain-lain sesuai dengan proses komunikasi yang dilakukan. Pengembangan behavioral 
dalam komunikasi antarbudaya dalam program acara Sandya Kala Gita di Radio Genta Bali yakni sebagai bentuk sosial dan sebagai bentuk pelestarian budaya.

\section{PENUTUP}

Proses komunikasi antarbudaya dalam program acara Sandya Kala Gita di Radio Genta Bali dapat dilihat jelas dalam segmentasi program acaranya yang mengutamakan konten budaya Bali dan agama Hindu. Proses penyiarannya telah sesuai dengan Trilogi Penyiaran dan Bahasa Bali menjadi bahasa pengantar dalam proses siaran program acara Sandya Kala Gita. Komunikasi antarbudaya dalam program acara Sandya Kala Gita mengalir secara jelas antara penyiar dan audiens pendengar dalam hubungan komunikasi antarpribadi, komunikasi kelompok serta komunikasi organisasi.

Fungsi komunikasi antarbudaya dalam program acara Sandya Kala Gita di Radio Genta Bali sangat vital. Terlihat jelas fungsi komunikasi antarbudaya dalam program acara Sandya Kala Gita tertuang sebagai fungsi pendidikan, fungsi sosial budaya, fungsi pelestarian budaya Bali dan agama Hindu serta berfungsi sebagai hiburan. Sedangkan implikasi komunikasi antarbudaya dalam program acara Sandya Kala Gita di Radio Genta Bali dapat dirasakan nyata efeknya oleh audiens pendengar baik secara kognitif, afektif maupun behavioral sehingga dipandang layak menjadi sumber informasi yang baik dan akurat. Selain sebagai hiburan program acara Sandya Kala Gita merupakan program acara unggulan di Radio Genta Bali dengan konsep dialog interaktif. Komunikasi terjadi dua arah antara komunikator dan komunikan, pesan yang disampaikan dapat diterima dengan baik serta feedback diperoleh dengan cepat.

Bagi Radio Genta Bali agar tetap menjaga eksistensinya sebagai media penyiaran yang menjunjung tinggi nilainilai budaya Bali dan agama Hindu terutama dalam melestarikan Bahasa Bali sebagai bahasa utama proses siaran. Khususnya dalam program acara Sandya Kala Gita supaya terus digali kearifan lokal budaya Bali dan agama Hindu agar tidak punah dan tetap lestari. Bagi Pemerintah agar berperan aktif dalam menjaga kelestarian budaya dengan menegakkan aturan yang sudah ada mengenai konsep budaya terutama dalam media penyiaran. Dan bagi peneliti selanjutnya, diharapkan untuk meneliti aspek-aspek yang belum terjangkau dalam penelitian ini.

\section{DAFTAR PUSTAKA}

Liliweri, Alo. 2011. Komunikasi Serba Ada Serba Makna. Jakarta : Kencana Prenada Media Group.

Morissan. 2013. Manajemen Media Penyiaran. Jakarta : Kencana Prenada Media Group.

Mulyana, Deddy, 2008. Komunikasi Massa. Bandung : Widya Padjadjaran.

Mulyana, Deddy, 2009. Komunikasi Antarbudaya. Bandung : PT. Remaja Rosdakarya.

Nurudin. 2007. Pengantar Komunikasi Massa. Jakarta : Raja Grafindo Persada.

Pace, R.Wayne dan Faules, Don F. 2006. Komunikasi

Organisasi. 
Bandung : PT. Remaja Rosdakarya.

Rohim, Syaiful. 2016. Teori Komunikasi Perspektif Ragam dan Aplikasi. Jakarta : Rineka Cipta.

Shoelhi, Mohammad. 2015. Komunikasi Lintas Budaya Dalam Dinamika Komunikasi International. Bandung : Simbiosa Rekatama Media.

Sihabudin, Ahmad. 2013. Komunikasi Antarbudaya : Satu Perspektif Multidimensi. Jakarta : Bumi Aksara.

Sugiyono. 2016. Metode Penelitian Kuantitatif Kualitatif dan R\&D. Bandung : Alfabeta.

Suranto, Aw. 2011. Komunikasi Interpersonal. Yogyakarta : Graha Ilmu. 